University of Nebraska - Lincoln

DigitalCommons@University of Nebraska - Lincoln

$1-30-2007$

\title{
Accounting for Agricultural Decline with Economic Growth in Taiwan
}

Ling Sun

Providence University, slwang@ers.usda.gov

LILYAN FULGINITI

University of Nebraska, Ifulginiti1@unl.edu

E. Wesley F. Peterson

University of Nebraska-Lincoln, epeterson1@unl.edu

Follow this and additional works at: https://digitalcommons.unl.edu/ageconfacpub

Part of the Agricultural and Resource Economics Commons

Sun, Ling; FULGINITI, LILYAN; and Peterson, E. Wesley F., "Accounting for Agricultural Decline with Economic Growth in Taiwan" (2007). Faculty Publications: Agricultural Economics. 22.

https://digitalcommons.unl.edu/ageconfacpub/22

This Article is brought to you for free and open access by the Agricultural Economics Department at DigitalCommons@University of Nebraska - Lincoln. It has been accepted for inclusion in Faculty Publications: Agricultural Economics by an authorized administrator of DigitalCommons@University of Nebraska - Lincoln. 
May 31, 2006

\title{
Accounting for Agricultural Decline with Economic Growth in Taiwan ${ }^{1}$
}

\author{
Ling Sun \\ Providence University \\ Lilyan E. Fulginiti \\ University of Nebraska- Lincoln \\ E. Wesley F. Peterson \\ University of Nebraska- Lincoln
}

${ }^{1}$ A contribution of the University of Nebraska Agricultural Research Division, Lincoln, NE 68583. Journal Series No. 14412 


\section{Accounting for Agricultural Decline with Economic Growth in Taiwan}

\section{Introduction}

Long-term economic growth has generally been associated with changes in sectoral contributions to economic output. Many authors have noted the substantial shift of labor from the agricultural sector to other economic sectors as growth proceeds (Anderson, 1987; Weisdorf, 2004; Kongsamut, et al., 2001). Lewis (1953) developed his surplus labor theory of economic development around a dual sector model with economic growth fueled by the transfer of labor from the relatively stagnant traditional agricultural sector to a modern capitalist sector. For Lewis, labor employed in traditional agriculture was in "unlimited supply" in the sense that it could be withdrawn without reducing agricultural output (its marginal product approached zero). Lewis saw agriculture as less productive than manufacturing, a view that is consistent with a long tradition in economics beginning with Smith and Ricardo (Martin and Mitra, 2001).

The movement of labor from traditional agriculture to the manufacturing and service sectors need not mean that agriculture is stagnant and incapable of growth. Martin and Mitra find that productivity growth between 1967 and 1992 was faster in agriculture than in manufacturing for a sample of 50 countries at various income levels. Mundlak also noted that substantial technological change in agriculture has made important contributions to overall economic growth by keeping food prices low and freeing up labor resources that could be employed in the growing manufacturing sectors. Mundlak points out, however, that the process of technical change in agriculture ultimately means that the share of agriculture in total output has declined (page 17). 
Anderson examined the reasons for the decline in agriculture's share of a growing economy. He noted that the decline in agricultural share could be explained for the world as a whole or for a small closed economy by relatively slow increases in food demand as a result of Engel's Law coupled with expanded agricultural output due to technological change. The effect of Engel's Law could be offset if technological change were sufficiently biased in favor of the non-farm (manufacturing) sector to give rise to a substantial increase in the relative price of food that would counter the decline in quantity (Anderson, 1987, p. 198). In small open economies, Anderson shows that a very strong bias in technological change in favor of agriculture could lead to an increase in the agricultural share if the effect on the quantities of food and non-food output were enough to offset the decline in relative prices (p. 198). It is unlikely that there would be such extreme biases in productivity gains for either sector. In the open-economy case, extreme bias in the growth of the agricultural sector is unlikely because of Rybczynski effects. Agriculture is thought to be labor-intensive while manufacturing is more capital-intensive. As a country's factor endowment begins to include more capital, resources will be withdrawn from the labor-intensive agricultural sector and transferred to the more capital-intensive manufacturing sector (Anderson, 1987, p. 198; Martin and Mitra, 2001, p. 406 and p. 417).

Taiwan is an example of a small, open economy in which there was initially an apparent comparative advantage in agricultural goods. In 1952, agricultural and processed agricultural products made up 92 percent of the value of Taiwan's exports. At that time, the agricultural sector's share in GDP was 32 percent. In 1997, the export share of agriculture and food products was 2.1 percent and the share of the agricultural sector in GDP was 2.7 percent. From the preceding discussion, such changes can be explained by technological change in agriculture, 
changes in preferences and relative prices (Engel's Law), and changes in factor endowments (Rybczynski effects). The purpose of this paper is to analyze the relative influence of these three sets of factors in accounting for the change in the agricultural share of GDP in Taiwan. In addition, the evolution of the agricultural share in Taiwan's GDP is decomposed to examine short-run variations and long-run factors.

Most studies of Taiwan's economic growth have focused on productivity growth rather than changes in economic structure (Young, 1995, 1994a, 1994b; Kim and Lau, 1994; Dessus et al., 1995; Fare et al., 1995; Chambers et al., 1996; Liang and Jorgenson, 1996; Fuess and Van Den Berg, 1996; Chang and Luh, 2000; Liang, 2002; Sun, 2002). Davies (1981) and Ho (1975) study structural change in the manufacturing sector while Kikuchi et al. (1978) and Cheng (1989) conduct historical analyses of the agricultural sector. In several papers on the newly industrialized countries in East Asia (Taiwan, South Korea, Hong Kong and Singapore), Young argues that the main cause of their rapid economic growth was factor deepening brought about by the transfer of labor from the traditional sector to the manufacturing sector and substantial capital accumulation (Young, 1995, 1994a, 1994b). He showed that productivity growth in these countries was not exceptionally high and suggested that outward-oriented policies were not the key to their rapid growth. From this perspective, the decline in agriculture's share of Taiwanese GDP contributed to the labor accumulation in the manufacturing sector that was of fundamental importance in the rapid economic growth experienced by that country.

In this paper, we develop an empirical model to decompose the evolution of the agricultural share of GDP into three components: price changes, factor endowment changes and technological change. We use an aggregate restricted GDP function based on theoretical models 
of Dixit and Norman (1980) that have been estimated by Kohli (1978), Diewert and Morisson (1998), Lau and Yotopoulas (1989), Martin and Warr (1993 and 1994), and Harrigan (1997). The results of the analysis shed light on the causes of the sectoral change which, according to Young (1994a, 1994b, 1995), was so important for Taiwan's overall economic growth experience and lead to conclusions about the significance of open market economic policies in the evolution of Taiwan's economy. In the following section, the theoretical model is formulated and the stochastic model is presented. The third section briefly describes the data used in the analysis. The estimates of the model parameters are then presented and discussed, followed by concluding comments.

\section{Theory and Model}

We assume a small open economy with competitive market clearing producing two outputs with three inputs. Production is joint as outputs compete for the use of fixed factor endowments. Since the estimation of the model is based on time series data, consideration of the nature of technical progress is possible. We assume that the aggregate technology satisfies constant returns to scale, free disposability and non-increasing marginal rates of substitution and transformation. Even if individual firms have decreasing returns, the assumption of constant returns can still be applied at the economy-wide level because changes in output can be achieved by changing the number of firms. Under profit maximization, the competitive equilibrium can be characterized as the solution to the problem of maximizing revenues subject to the technology, the endowment of domestic resources and a vector of positive output prices at each point in time. Let $T(t)$ be the production possibilities set at time $t$. We can then present the technology as the following GDP function (Kohli, 1978, 1991, Woodland, 1977): 


$$
\begin{aligned}
& \pi\left(\boldsymbol{p}_{t}, \boldsymbol{x}_{t}, t\right)=\underset{\boldsymbol{y}_{t}}{\max }\left\{\boldsymbol{p}_{.}{ }_{t} \boldsymbol{y}_{t}:\left(\boldsymbol{y}_{t}, \boldsymbol{x}_{t}\right) \in T(t)\right\} \\
& \boldsymbol{p}, \boldsymbol{y} \in \mathbb{R}^{2}, \boldsymbol{x} \in \mathbb{R}^{3},
\end{aligned}
$$

where $y$ is the vector of final goods, i.e. agricultural products $(A)$ and nonagricultural products $(N), \boldsymbol{p}$ is the vector of final goods prices $\left(P_{a}\right.$ and $\left.P_{n}\right), \boldsymbol{x}$ is a vector of factor endowments that include labor $(L)$, capital $(K)$ and resources $(R), T(t)$ is a convex production set and $t$ (time) is used as a proxy for technical change. The GDP function is linearly homogeneous and convex in output prices and is non-decreasing in both the prices and quantities of outputs.

For empirical purposes a translog function is used to represent GDP. Without the time subscript, the $G D P$ function is:

$$
\begin{aligned}
& \ln \pi=\alpha_{0}+\Sigma_{i} \alpha_{i} \ln p_{i}+1 / 2 \Sigma_{i} \Sigma_{h} \alpha_{i h} \ln p_{i} \ln p_{h}+\Sigma_{j} \beta_{j} \ln x_{j}+1 / 2 \Sigma_{j} \Sigma_{k} \beta_{j k} \ln x_{j} \ln x_{k} \\
& +\Sigma_{i} \Sigma_{j} \gamma_{i j} \ln p_{i} \ln x_{j}+\Sigma_{i} \gamma_{i t} \ln p_{i} t+\Sigma_{j} \gamma_{j t} \ln x_{j} t+\Phi_{t} t+1 / 2 \Phi_{t t} t^{2} \\
& \quad i \in\{A, N\}, j \in\{L, K, R\}
\end{aligned}
$$

where $p_{i}$ represents output prices; $x_{j}$ represents quantities of factor endowments, and $t$ is time. Symmetry and linear homogeneity in $\boldsymbol{x}$ (constant returns to scale) and in $\boldsymbol{p}$ are imposed using the following restrictions:

$$
\begin{aligned}
& \Sigma_{i} \alpha_{i}=1 ; \quad \Sigma_{j} \beta_{j}=1 ; \Sigma_{h} \alpha_{i h}=0 ; \quad \Sigma_{k} \beta_{j k}=0 ; \quad \Sigma_{j} \gamma_{i j}=0 ; \quad \Sigma_{i} \gamma_{i j}=0 ; \Sigma_{i} \gamma_{i t}=0 ; \Sigma_{j} \gamma_{j t}=0 \\
& \alpha_{i h}=\alpha_{h i} ; \beta_{j k}=\beta_{k j} ; \gamma_{i j}=\gamma_{j i}
\end{aligned}
$$

According to Hotelling's Lemma, the vector of net output supplies $y_{i}(\boldsymbol{p}, \boldsymbol{x})$ is given by the gradient of $\pi\left(\boldsymbol{p}_{t}, \boldsymbol{x}_{t}, t\right)$ with respect to $\boldsymbol{p}$. The Translog functional form allows us to represent the output supply in terms of shares. The partial derivative of $\ln \pi$ with respect to $\ln p_{a}$ once the 
homogeneity restrictions in (3) are imposed is the agricultural share $\left(S_{a}\right)$ :

$$
S_{a}=\alpha_{a}+\alpha_{a a} \ln p_{a}+\left(-\alpha_{a a}\right) \ln p_{n}+\gamma_{a L} \ln L+\gamma_{a K} \ln K+\left(-\gamma_{a L}-\gamma_{a K}\right) \ln R+\gamma_{a t} t \text { (4) }
$$

Equation (4) can be rewritten:

$$
S_{a}=\alpha_{0}+\alpha_{1} \ln \left(p_{a} / p_{n}\right)+\gamma_{1} \ln (K / L)+\gamma_{2} \ln (R / L)+\gamma_{3} t
$$

This equation is used later to understand how changes in output prices, factor endowments and technical change account for the decline in the GDP share of the agricultural sector in Taiwan.

\section{Data}

To estimate equation (5) we need data on agricultural share, output prices and factor endowments. The agricultural price used is the GDP deflator of the agricultural sector. The nonagricultural price is a weighted average of different sectors' GDP deflators with weights

given by their contributions to overall GDP. A reviewer has suggested that representing Taiwan as a small open economy is inappropriate because widespread domestic price distortions mean that relative prices in Taiwan differ from the corresponding world prices. Domestic prices, whether distorted or not, are the prices that have influenced the evolution of the agricultural share in Taiwan, however. As we shall see later, the empirical analysis supports the presence of Rybczynski effects and this result is consistent with the assumption of a small open economy.

The factors we consider in this model are capital $(K)$, labor $(L)$ and land (or natural resources, $R$ ). These factors are modeled as quasi-fixed only within the annual observation period, and allowance is made for adjustments and interactions through time as will become 
clear later. The capital stock series was constructed using a perpetual inventory method with an annual depreciation rate of 5 percent:

$$
K_{t}=(1-d) K_{t-1}+I_{t}
$$

where $K$ is capital stock at the end of each year, $d$ is the depreciation rate, $I$ is investment. A level of physical capital stock is estimated for 1966 following Harberger's (1978) method of estimation of the capital stock at the steady state. First, we assume a steady-state relation:

$$
I^{*}=(g+d) K^{*}
$$

The initial capital stock can be retrieved from:

$$
K^{*}=I^{*} /(g+d)
$$

where $I^{*}$ is the steady state level of investment, $g$ is the rate of growth of real investment (and capital), $d$ is the rate of depreciation and $K^{*}$ is the steady-state capital stock. Second, we estimate the growth rate $g$ by

$$
\ln I=\tau_{0}+\tau_{1} t
$$

where $t$ is time and the coefficient of $t$ is the growth rate of real investment, $g$. Employing a 5 percent depreciation rate we can obtain the initial capital stock in the first period of the sample from the steady-state relation. Then by adding investment during the previous period and deducting depreciation we can rebuild the capital stock series.

As for labor endowments, Darby (1984) suggests that labor stock data should be adjusted to embody human capital. We therefore include the average number of years of schooling for 
the labor force as a proxy for human capital. $\mathrm{L}$ is given as:

$$
L_{t}=h_{t} l_{t}
$$

where

$$
h_{t}=e^{\psi E t}
$$

is the human capital embodied per unit of labor force, $E$ is the average school years for the labor force, and $l$ is the labor force. Equation (10) can be expressed:

$$
L_{t}=(1+\psi)^{E t} l_{t}
$$

Following Darby, we assume $\psi=0.07$, which means human capital per worker increases 7 percent per school year.

Land in use in Taiwan has not shown a significant change in the last 30 years. The most obvious change is the transformation from the use of land for agriculture to nonagricultural activities, but such changes have been small. However, due to the growth of the adjusted labor force, the ratio of $R$ to $L$ has declined. The time series data are shown in Appendix Table A-1.

The data used in this paper are annual series drawn primarily from the Taiwan Statistical Data Book (2002), Quarterly National Economic Trends Taiwan Area, the Republic of China (2000) and the Monthly Bulletin of Earnings and Productivity Statistics, the Republic of China (2000).

The full sample period is 1967 to 1997 . The real GDP in the agricultural sector is presented in Figure 1, and the share of agriculture in GDP is presented in Figure 2. The two diagrams show that even though there is substantial growth in the value of agricultural output over the last 30 years, the share of agriculture in GDP has declined. The price of agricultural output in relation to nonagricultural output is plotted in Figure 3. No substantial trend in the relative prices is evident. There does not appear to be much relation between relative agricultural prices and the share of agriculture in GDP although the increase in relative price between 1973 
and 1975 does seem to correspond to a brief increase in agriculture's share of GDP. The capitallabor ratio computed as described above is depicted in Figure 4. This series shows a smooth increase in the 1970s and 1980s. After 1989, the rate of growth of the capital-labor ratio increases more rapidly because the rate of investment increased per unit of labor. The declining ratio of land to labor is shown in Figure 5. 
Figure 1. GDP in the Agriculture Sector in Taiwan, 1967-1997 (1991 prices)

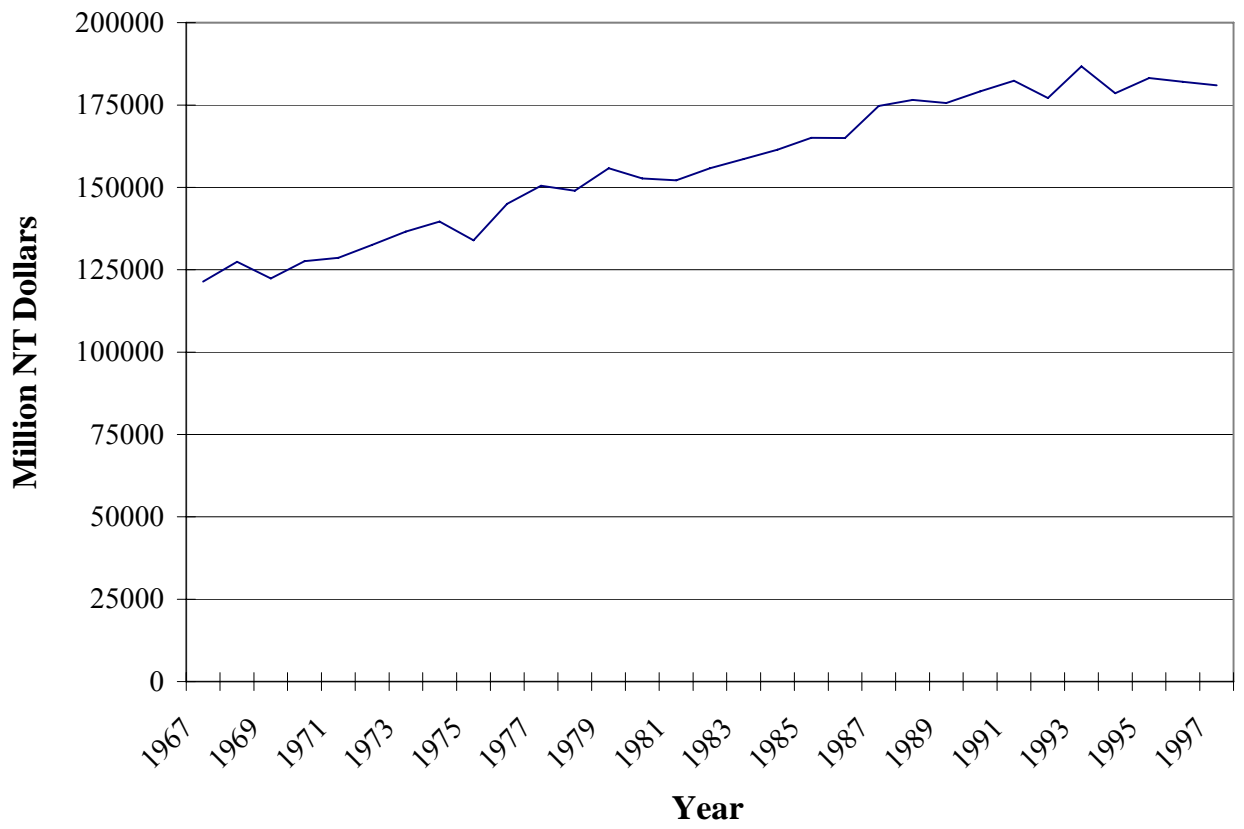


Figure 2. Agricultural Share in Taiwanese GDP, 1967-1997

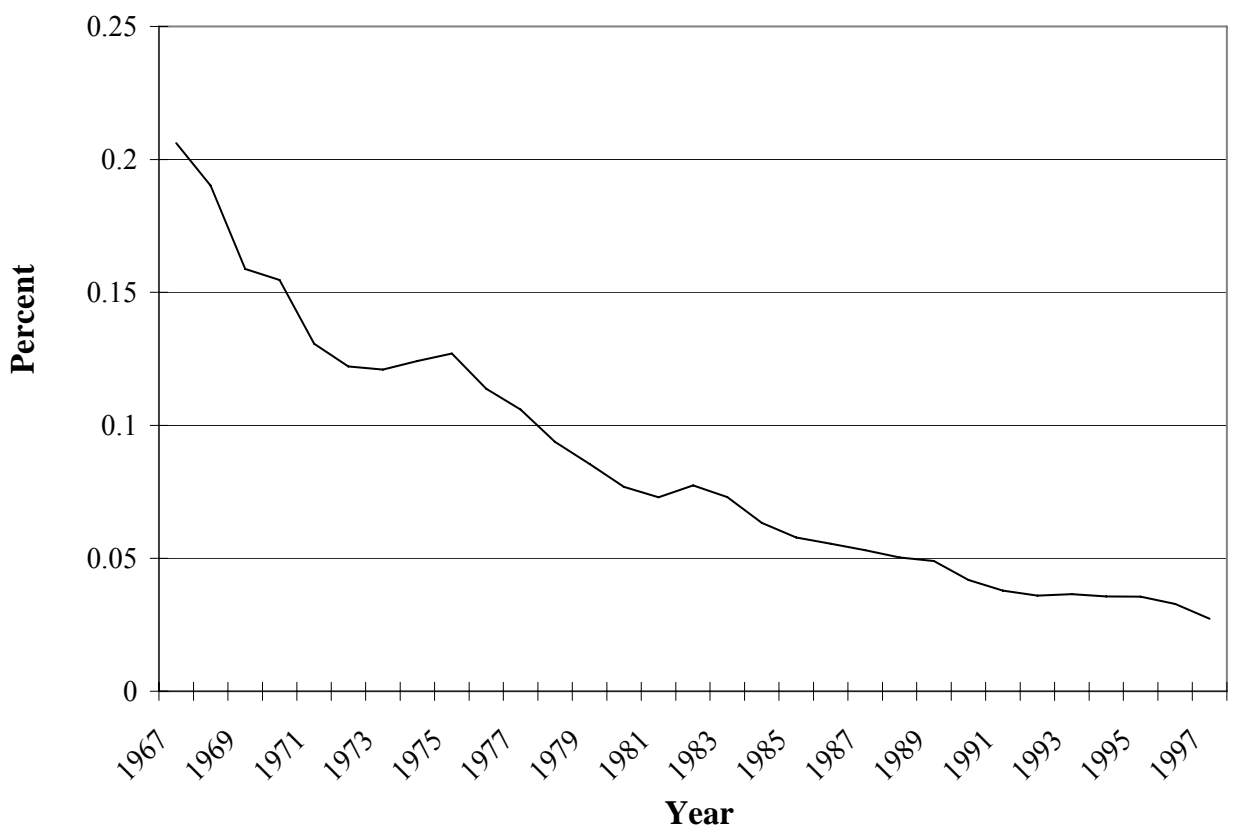


Figure 3. Index of Relative Prices of the Agricultural and Nonagricultural Outputs

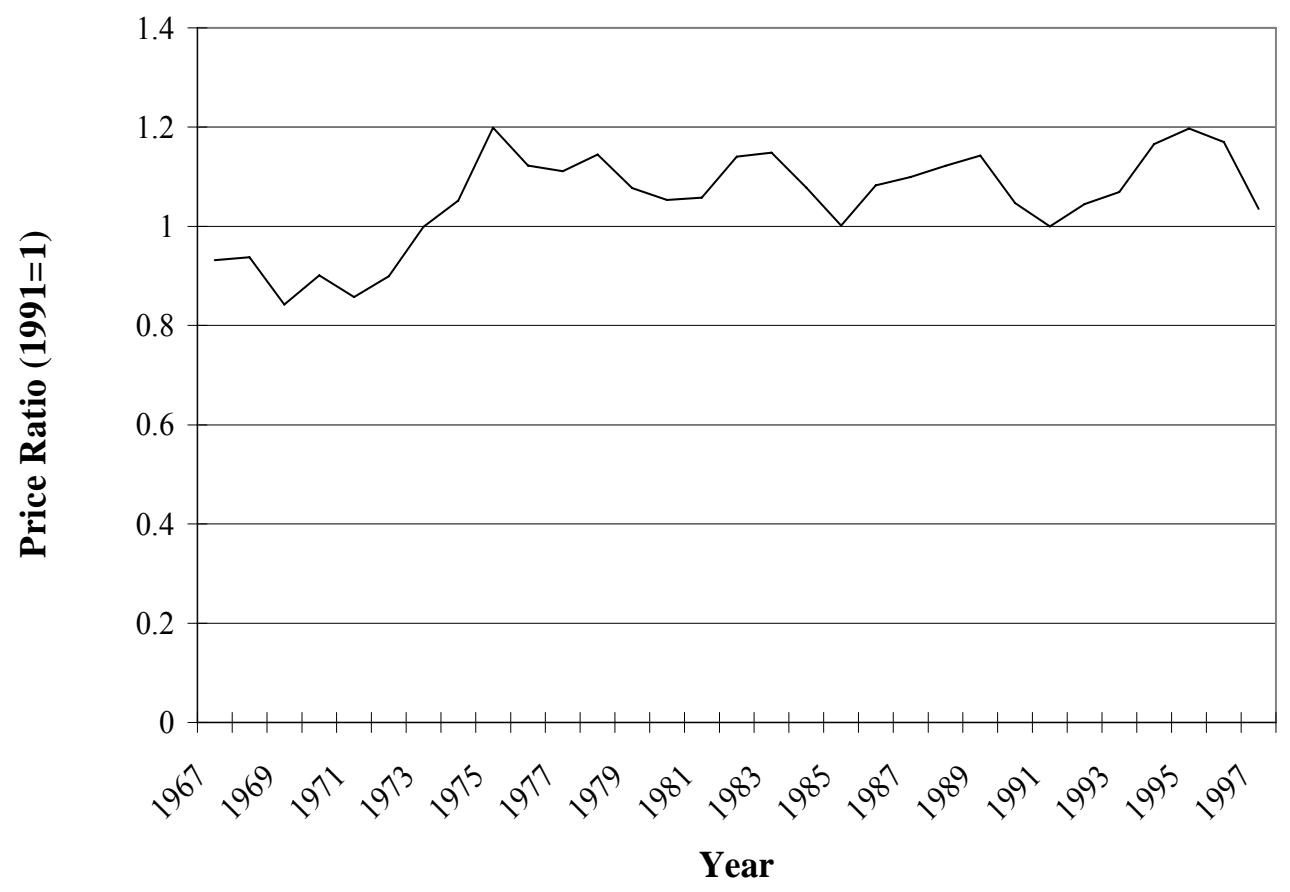


Figure 4. The Capital-Labor Ratio in Taiman, 1967-1997

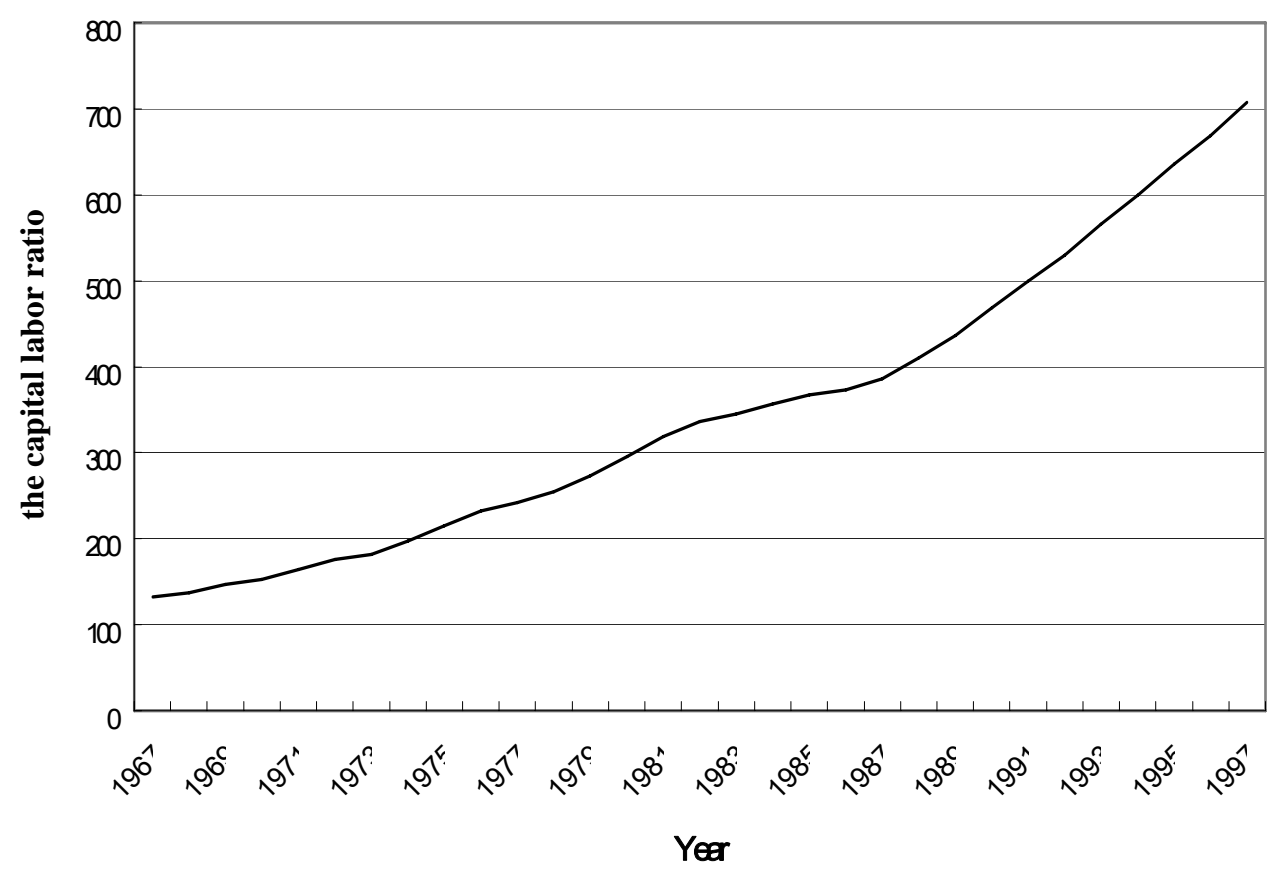


Figure 5. The Land-Labor Ratio in Taiwan, 1967-1997

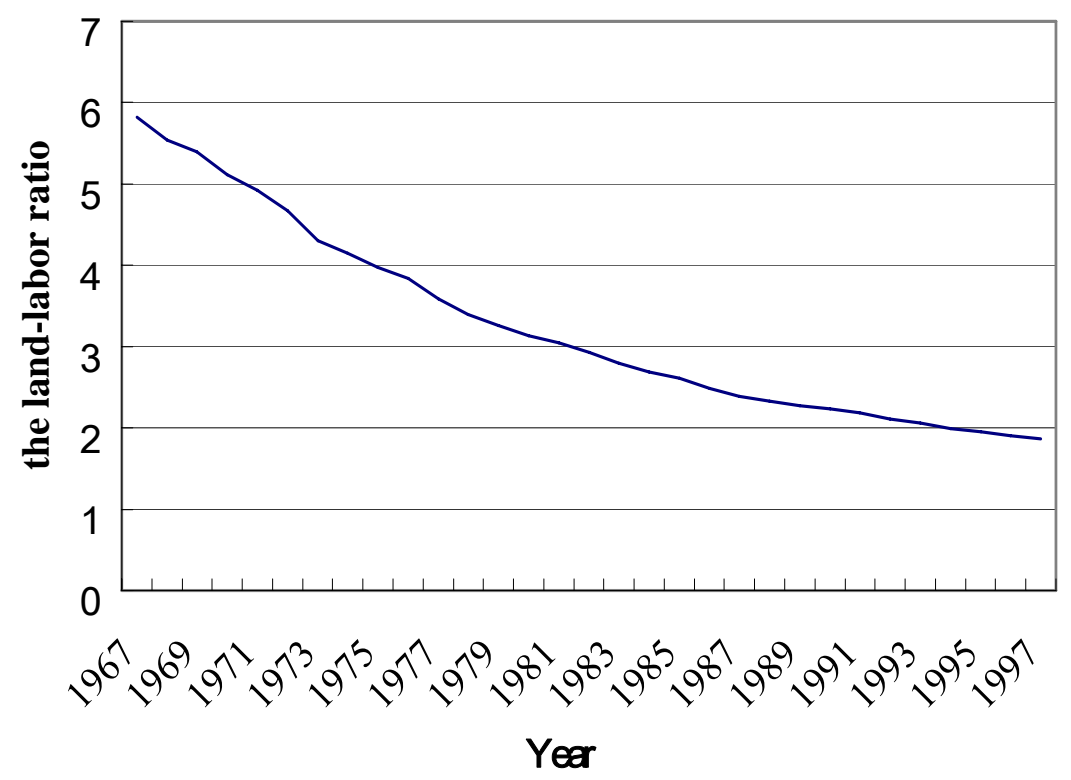




\section{Empirical Results}

The data were first tested to assess whether the variables are non-stationary.

Regressions involving independent non-stationary variables tend to generate spurious results. The standard method for detecting non-stationary behavior in a time series is to test for the presence of a unit root. A variable that has a unit root but whose first differences are stationary is referred to as being integrated of order one and is denoted as $I(1)$. We can difference the variables prior to estimation to get consistent estimates of the model coefficients when the variables are not co-integrated. If variables are co-integrated, however, there is a long-run relation between the 'integrated' economic variables. In such cases, the relationship can be represented with an error-correction model (ECM).

We add an error term to Equation (5) to represent the long-run relation between the agricultural share, prices, factor endowments and technology, with $a_{0}, a_{1}, a_{2}, a_{3}, a_{4}$ the parameters to be estimated in the empirical model.

$$
S_{a}=a_{0}+a_{1} \ln \left(p_{a} / p_{n}\right)+a_{2} \ln (K / L)+a_{3} \ln (R / L)+a_{4} t+u_{t}
$$

The ECM equation in first differences is:

$$
\Delta S_{a}=a_{4}+a_{1} \Delta \ln \left(p_{a} / p_{n}\right)+a_{2} \Delta \ln (K / L)+a_{3} \Delta \ln (R / L)+\left(u_{t}-u_{t-1}\right)
$$

where $\Delta$ is the first-difference operator. If $u_{t}$ is serially correlated,

$$
u_{t}=\rho u_{t-1}+\varepsilon_{t},
$$

with $\varepsilon_{t}$ distributed with zero mean and finite variance, (14) can be rewritten as:

$$
\Delta S_{a}=a_{4}+a_{1} \Delta \ln \left(p_{a} / p_{n}\right)+a_{2} \Delta \ln (K / L)+a_{3} \Delta \ln (R / L)+\lambda u_{t-1}+\varepsilon_{t}
$$

where $\lambda=(\rho-1)$. If $\rho=1$ then $u_{t}$ is non-stationary and $\lambda$ is zero. In this case the first-differences 
specification in (14) does not include the term $\left(u_{t}-u_{t-1}\right)$ and the equation can be consistently estimated by OLS. However the estimated coefficients do not carry the same interpretation as the coefficients in equation (13) since equation (14) will be a dynamic specification measuring the short-run effects of changes but not of levels. When $\rho$ is smaller than unity so that $u_{t}$ is stationary then $\lambda$ will be different from zero and the error correction term should be included in the dynamic ECM specification of (14). Estimating the specification in first differences without the error correction term will not provide consistent estimates, as changes in the agricultural share will be affected by deviations from the steady state.

A number of tests for stationarity are available such as the Dickey-Fuller test (1984) and the Phillips-Perron test (1988). Table 1 presents the results of the standard Dickey-Fuller (DF) and the augmented Dickey-Fuller (ADF) tests. Results suggest that the relative price ratio and the resources per worker do not have unit roots while we cannot reject the unit roots hypothesis for the capital per worker and agricultural share variables. Since the agricultural share and the relative capital labor ratio are $I(1)$, the co-integrating relationship of these variables is examined further. According to Lee and Granger (1990), it is possible to find equilibrium relationships among groups of variables that are integrated of different orders. They refer to this circumstance as “multicointegration”. Both Granger type residual tests (shown in Table 1) and the Johansen test (shown in Table 2) were conducted to identify the cointegration relationship among the variables. These tests and all econometric analysis were undertaken using SHAZAM. Tests indicate rejection of the hypothesis of no co-integrating relationship among the variables. The results confirm a long-run relationship among the variables of interest. 
Table 1. Results for the Stationarity and Cointegration Tests

\begin{tabular}{llll}
\hline variables & D-F test & ADF test & Number of lags for ADF \\
$\mathrm{Sa}$ & -1.37 & -2.52 & 4 \\
$\ln (\mathrm{Pa} / \mathrm{Pn})$ & $-3.68 * *$ & $-4.35 * *$ & 1 \\
$\ln (\mathrm{K} / \mathrm{L})$ & -0.83 & -0.41 & 1 \\
$\ln (\mathrm{R} / \mathrm{L})$ & $-5.23 * *$ & $-4.72 * *$ & 2 \\
Residual & $-5.36 * *$ & & \\
& & & \\
\hline
\end{tabular}

1. '**' indicates significance at the 5 percent level. The 5 percent critical value for DF and ADF test is -3.0 , 10 percent critical value is -2.63 . When there is a smaller number than the critical value we reject the hypothesis of unit root.

2. Number of lags for ADF test is decided by the AIC criterion.

3. The cointegration test was conducted with a DF test of the residual from the long-run equilibrium. The Cochrane-Orcutt approach was used in estimating the long-run relationship function.

Table 2. Results for the Johansen Cointegration Tests

\begin{tabular}{ccc}
\hline $\mathrm{r}$ & Trace statistic & Maximal eigenvalue statistic \\
3. & 0.201 & 0.201 \\
2. & 14.955 & $14.754^{* *}$ \\
1. & $58.650 * *$ & $43.695^{* *}$ \\
0. & $121.811 * *$ & $63.161^{* *}$ \\
\hline
\end{tabular}

1. $\mathrm{r}=$ number of cointegrating vectors. Null hypothesis: No. of cointegrating vectors is less than or equal to $r$.

2. “**” indicates significant at $5 \%$ level. 
Equation (13) was first estimated with OLS. Since there is an autoregressive problem in the estimation, we also report the results obtained using the Cochrane-Orcutt approach (shown as part A in Table 3). Because the agricultural share and the relative capital-labor ratio are I(1) with a co-integration relationship between these variables, the error correction model is a more appropriate specification. Besides using the two-step approach of Engle and Granger (1989) in estimating the error correction model, we also formulate a more general model by introducing the lagged changes of each variable into equation (16) as indicated by the Akaike's Information Criterion:

$$
\begin{aligned}
\Delta S_{a}=b_{0} & +\Sigma b_{1 s} \Delta S_{a t-s-l}+\Sigma b_{2 s} \Delta \ln \left(p_{a} / p_{n}\right)_{t-s}+\Sigma b_{3 s} \Delta \ln (K / L)_{t-s}+\Sigma b_{4 s} \Delta \ln (R / L)_{t-s} \\
& +\lambda u_{t-1}+\varepsilon_{t}
\end{aligned}
$$

Short-run and long-run parameters can be estimated jointly by replacing $u_{t-1}$ in Equation (17) with Equation (13):

$$
\begin{aligned}
\Delta S_{a}= & b_{0}+\Sigma b_{1 s} \Delta S_{a t-s-l}+\Sigma b_{2 s} \Delta \ln \left(p_{a} / p_{n}\right)_{t-s}+\Sigma b_{3 s} \Delta \ln (K / L)_{t-s}+\Sigma b_{4 s} \Delta \ln (R / L)_{t-s} \\
& +\lambda\left(S_{a t-1}-a_{0}-a_{1} \ln \left(p_{a} / p_{n}\right)_{t-1}-a_{2} \ln (K / L)_{t-1}-a_{3} \ln (R / L)_{t-1}-a_{4} t_{t-1}\right)+\varepsilon_{t}
\end{aligned}
$$

or equivalently as:

$$
\begin{aligned}
& \Delta S_{a}=c_{0}+\sum b_{1 s} \Delta S_{a t-s-l}+\Sigma b_{2 s} \Delta \ln \left(p_{a} / p_{n}\right)_{t-s}+\Sigma b_{3 s} \Delta \ln (K / L)_{t-s}+\Sigma b_{4 s} \Delta \ln (R / L)_{t-s} \\
& \quad+c_{1} S_{a t-1}+c_{2} \ln \left(p_{a} / p_{n}\right)_{t-1}+c_{3} \ln (K / L)_{t-1}+c_{4} \ln (R / L)_{t-1}+c_{5} t_{t-1}+\varepsilon_{t}
\end{aligned}
$$

where $c_{0}=b_{0}-a_{0} \lambda$

$$
\begin{aligned}
& c_{1}=\lambda \\
& c_{2}=-a_{1} \lambda \\
& c_{3}=-a_{2} \lambda \\
& c_{4}=-a_{3} \lambda
\end{aligned}
$$




$$
c_{5}=-a_{4} \lambda
$$

and from which we can recover the long-run parameters of (13):

$$
\begin{aligned}
& a_{1}=-c_{2} / \lambda \\
& a_{2}=-c_{3} / \lambda \\
& a_{3}=-c_{4} / \lambda \\
& a_{4}=-c_{5} / \lambda \\
& a_{0}=\left(b_{0}-c_{0}\right) / \lambda
\end{aligned}
$$

One feature of estimating (19) that is of interest in this study is the possibility of identifying not only the steady state equilibrium relationship represented by the vector of $a$ 's but also of obtaining information about the path of the variables towards that long-run equilibrium which is captured by the vector of $b$ 's and c's. Results are presented in Table 3, B and C.

From the Engle Granger two-step estimate, the negative sign for $u_{t-1}$ in equation (17) demonstrates adjustment to the long-run relationship. From the dynamic and the long-run parameters in $\mathrm{B}(\mathrm{i}-\mathrm{ii})$ and $\mathrm{C}$ (Table 3$)$, we can see that each of the estimated equations has a positive gradient with respect to the level and the change of the price ratio. This indicates that when the relative price of agricultural products increases so does the share of the sector (the result of $\mathrm{C})$ and it does so at an increasing rate $\left(\Delta S_{a}\right.$, the results of B(i)-(ii)). Although not significant, the negative sign for the coefficient of the capital-labor ratio suggests that it is inversely related to agriculture's share in GDP as well as to its change. Since the coefficient of $\mathrm{K} / \mathrm{L}$ is recovered from the results in $\mathrm{B}$, its insignificance may be the result of multicollinearity in $\mathrm{B}$ due to a high correlation between $\ln (\mathrm{K} / \mathrm{L})_{\mathrm{t}-1}$ and $\mathrm{Sa}_{\mathrm{t}-1}$. The results in A show a significant negative relationship between $\mathrm{K} / \mathrm{L}$ and the agricultural share and given that the level variables 
are co-integrated, these results may be a better estimate of this relationship. The implication of this analysis is that even when technological change is biased in favor of the agricultural sector, as shown by the coefficient of time, agriculture's contribution to the economy shrinks, mainly because of the large influx of capital that benefited the rest of the economy.

These results are also consistent with the Rybczynski Theorem, which hypothesizes that an increase in the endowment of one factor will increase the output of the commodity intensive in that factor and will reduce the output of other commodities. Since agriculture is relatively labor intensive, the rapid accumulation of capital will cause a relative decline of the agricultural sector's share. As to the influence of land per unit of labor, the positive sign indicates that the declining land-labor ratio may be responsible for some of the decrease of the agricultural share. The coefficient of time shows that technical change has been biased in favor of agriculture.

The significant negative sign for the coefficient of $\Delta \ln (K / L)_{t}$ in B-(i)equation (17) shows that the increase in the accumulation of capital stock may result in a decline in the change of the agriculture share. On the other hand the significant coefficients for lagged shares indicate that dynamic adjustments are important in the production process. ${ }^{1}$

We use the long-run parameters from part $\mathrm{C}$ in Table 3 to calculate output supplies and transformation elasticities. Even though the elasticities at the mean, shown in Table 3, have the expected sign, in 8 out of 29 observations the curvature condition is violated indicating lack of global convexity of the translog GDP function. The supply elasticity of nonagricultural products

1 As Nerlove (1956) has shown, this particular reduced form could alternatively be capturing price expectations instead of dynamic adjustment. It is a maintained hypothesis in our paper that price expectations are static and that the lagged shares represent dynamic production adjustment. 
at the mean is smaller than that of agricultural products. The transformation elasticity between the two sectors is negative indicating substitutability.

If the regressors of a model are asymptotically correlated with the contemporaneous disturbance of the model, the coefficient estimated by OLS may be inconsistent (Beggs, 1988). A weak exogeneity test (Ericsson, 1992) is used to examine this potential problem for both the OLS model and the ECM model. T-tests for the significance of the lagged residual from equation (13) as an explanation of $\ln \left(P_{a} / P_{n}\right), \ln (K / L)$ and $\ln (R / L)$ in the OLS estimation and for the lagged residual in equation (19) as an explanation of $\Delta \ln \left(P_{a} / P_{n}\right), \Delta \ln (K / L), \Delta \ln (R / L)$ in the ECM model are used. The tests indicate an absence of simultaneous equation bias, confirming the validity of the single equation model used in this paper.

Decomposition of the change of the agricultural share, equation (19), into short-run and long run effects using estimates in Table $3 \mathrm{~B}$ (ii), is illustrated in Figure 6. The short run effects reflect the combined impacts of changes in the contemporaneous values $P_{a} / P_{n}, K / L$ and $R / L$. The long run effects result from the joint influence of changes in lagged values of $S_{a}, P_{a} / P_{n}, K / L, R / L$ and technical change. Figure 6 shows the combined short and long run effects. Our estimates indicate that the change in the agricultural share of GDP, its dynamic behavior, is significantly impacted by the past values of these variables, the long-run effect. These results indicate that the speed of adjustment of $S_{a}$ to a new steady state will depend crucially on the level of the variables at the initial steady state, more than on how the specific dynamic paths of these variables evolve. 
Table 3. The econometric results of alternative specifications

A. The OLS estimation of agriculture share --equation (5)

$\mathrm{S}_{\mathrm{a}}=0.07456+0.08512 \ln \left(\mathrm{p}_{\mathrm{a}} / \mathrm{p}_{\mathrm{n}}\right)_{\mathrm{t}}-0.08278 \ln (\mathrm{K} / \mathrm{L})_{\mathrm{t}}+0.28659 \ln (\mathrm{R} / \mathrm{L})+0.01007 \mathrm{t}+\mathrm{u}_{\mathrm{t}}$
$(0.2825)$
$(3.23)^{* *}$
$(-1.69)^{*}$
$(6.7)^{* * *}$
$(3.629)^{* * *}$

$\mathrm{R}^{2}=0.9716$, adjusted $\mathrm{R}^{2}=0.9672$, D.W. $=0.4356$

RESET(2) 342.84***

Estimation by using the Cochrane-Orcutt approach--equation (5)

$\mathrm{S}_{\mathrm{a}}=0.16215+0.09881 \ln \left(\mathrm{p}_{\mathrm{a}} / \mathrm{p}_{\mathrm{n}}\right)_{\mathrm{t}}-0.10693 \ln (\mathrm{K} / \mathrm{L})_{\mathrm{t}}+0.30867 \ln (\mathrm{R} / \mathrm{L})+0.01183 \mathrm{t}+\mathrm{u}_{\mathrm{t}}$
(0.5569)
$(4.953) * * *$
$(-1.825)^{*}$
$(4.701)^{* * *}$
$(2.704)^{* *}$

$\mathrm{R}^{2}=0.9880$, adjusted $\mathrm{R}^{2}=0.9862, \quad \mathrm{D} . \mathrm{W} .=1.3749, \quad \mathrm{RHO}=0.77476(6.82277)^{* * *}$

$\operatorname{RESET}(2) 123.19 * * *$

B. The ECM of change of agriculture share

(i) Engle-Granger two-steps estimation--equation (17)

$$
\begin{aligned}
& \Delta \mathrm{S}_{\mathrm{a}}=0.018965+0.32249 \Delta \mathrm{S}_{\mathrm{a}-1}+0.082889 \Delta \ln \left(\mathrm{p}_{\mathrm{a}} / \mathrm{p}_{\mathrm{n}}\right)_{\mathrm{t}}-0.04346 \Delta \ln \left(\mathrm{p}_{\mathrm{a}} / \mathrm{p}_{\mathrm{n}}\right)_{\mathrm{t}-1}-0.2226 \Delta \ln (\mathrm{K} / \mathrm{L})_{\mathrm{t}} \\
& (3.591)^{* * *} \quad(2.103)^{* *} \quad(5.754)^{* * *} \quad(-2.074)^{* *} \quad(-2.86)^{* * *} \\
& +0.0256 \Delta \ln (\mathrm{K} / \mathrm{L})_{\mathrm{t}-1}+0.42946 \Delta \ln (\mathrm{R} / \mathrm{L})_{\mathrm{t}}-0.102 \Delta \ln (\mathrm{R} / \mathrm{L})_{\mathrm{t}-1}-0.73518 \mathrm{u}_{\mathrm{t}-1} 1+\varepsilon_{t} \\
& (0.617) \quad(4.317)^{* * *} \quad(2.936)^{* *} \quad(-4.7)^{* * *}
\end{aligned}
$$

(ii) One step estimation with lagged level variables-equation(19)

$$
\begin{aligned}
& \Delta \mathrm{S}_{\mathrm{a}}=-0.016154+0.080252 \Delta \ln \left(\mathrm{p}_{\mathrm{a}} / \mathrm{p}_{\mathrm{n}}\right)_{\mathrm{t}}-0.1303 \Delta \ln (\mathrm{K} / \mathrm{L})_{\mathrm{t}}+0.30117 \Delta \ln (\mathrm{R} / \mathrm{L})_{\mathrm{t}}-0.67303 \mathrm{~S}_{\mathrm{at}-1} \\
& \begin{array}{lllll}
(-0.1515) & (6.123)^{* * *} & (-2.074)^{* *} & (2.669)^{* *} & (-4.706)^{* * *}
\end{array} \\
& +0.058536 \ln \left(\mathrm{p}_{\mathrm{a}} / \mathrm{p}_{\mathrm{n}}\right)_{\mathrm{t}-1}-0.026293 \ln (\mathrm{K} / \mathrm{L})_{\mathrm{t}-1}+0.15353 \ln (\mathrm{R} / \mathrm{L})_{\mathrm{t}-1}+0.0038639 \mathrm{t}_{\mathrm{t}-1}+\varepsilon_{t} \\
& (3.475)^{* * *} \quad(-1.214) \quad(3.611)^{* * *} \quad(2.438)^{* *}
\end{aligned}
$$

$\mathrm{R}^{2}=0.8718$, adjusted $\mathrm{R}^{2}=0.8205$, D.W. $=2.1185$

RESET(2) -8.2395

C. The long run relationship derived from the ECM with the nonlinear method of equation (20) and (21)

$$
\begin{aligned}
& \mathrm{S}_{\mathrm{a} t}=-0.05624+0.086974 \ln \left(\mathrm{p}_{\mathrm{a}} / \mathrm{p}_{\mathrm{n}}\right)_{\mathrm{t}}-0.03907 \ln (\mathrm{K} / \mathrm{L})_{\mathrm{t}}+0.22812 \ln (\mathrm{R} / \mathrm{L})+0.00574 \mathrm{t}+\mathrm{u}_{\mathrm{t}} \\
& (4.89)^{* * *} \quad(-1.31) \\
& \varepsilon_{\mathrm{aa}}=0.398121, \varepsilon_{\mathrm{nn}}=0.086974, \tau_{\mathrm{an}}=\tau_{\mathrm{na}}=-0.42591
\end{aligned}
$$

1:The number inside the parenthesis is the $\mathrm{t}$ ratio, and the $\mathrm{t}$ statistic is 2.228 at a $95 \%$ confidence level and 1.812 at a $90 \%$ confidence level. 2 . A “**” indicates significance at the 5 percent level, “*” indicates significance at the 10 percent level.

3. The $t$ ratios for the coefficients of the long run relationship were retrieved from the underlying nonlinear approximation.

4. $\varepsilon_{\mathrm{aa}}$ and $\varepsilon_{\mathrm{nn}}$ are supply elasticities of agriculture and nonagriculture output at the mean. $\tau_{\mathrm{an}}$ and $\tau_{\mathrm{na}}$ are transformation elasticities between agriculture and nonagriculture outputs.

5. Ramsey RESET(2) tests are based on the $t$ test for significance of the incorporated squared predicted value. 
Figure 7 decomposes the changes in the agricultural share of GDP into that portion explained by relative prices, inputs, technical change and past values of the agricultural share. It uses equation (19) and the parameter estimates in Table 3 B (ii). Each line includes both short term dynamic changes and long-run equilibrium levels for each of the variables. This can be interpreted as an exercise in growth decomposition of the dynamic behavior of the agricultural share. This exercise complements that of Figure 6 as it indicates how the evolution of each variable as well as their initial levels has influenced the dynamic path of the agricultural share. We learn that the land-labor ratio makes positive but declining contributions to the change in agricultural share, while the capital-labor ratio has an increasingly negative effect. Technical change seems to be increasingly biased for agriculture while relative prices have almost no effect.

Figure 8 shows the same exercise of decomposition of the agricultural share itself, instead of its change. It plots the components of the $S_{a}$ equation in Table $3 \mathrm{C}$. This shows that in steady state, the agricultural share of GDP in Taiwan has been influenced mostly by the evolution of inputs, in particular by the capital-labor ratio.

In Table 4 we see that the agricultural share of GDP in Taiwan has decreased from an average of 12 percent in the 1970 s to 6 percent in the 1980 s to 2.5 percent in the 1990 s. Using the estimates in Table $3 \mathrm{C}$ we are able to complement Figure 8 with a 'growth-decomposition' analysis that indicates the average impact of each of the relative prices, endowments, and technical change on the evolution of the steady state level of the share of the agricultural sector. Table 4 reinforces the results in Figure 8 indicating that flows of resources out of the sector are the most important determinant of the reduction in the steady state level of the agricultural share 
in Taiwan. Relative price changes have had a minor and ambiguous effect while technical change has been in favor of the sector but its impact has been drowned by the resource drain.

Table 4. Impact of the change in relative prices, endowments, and technical change on the evolution of the share of agriculture in Taiwan, in steady state.

\begin{tabular}{|c|c|c|c|c|c|}
\hline Period & Relative prices & Capital/Labor & Land/Labor & $\begin{array}{l}\text { Technical } \\
\text { change }\end{array}$ & $\begin{array}{l}\text { Average } \\
\text { agricultural } \\
\text { share }\end{array}$ \\
\hline 1968-1977 & 0.015 & -0.022 & -0.099 & 0.051 & 12.0 \\
\hline $1978-1987$ & -0.003 & -0.016 & -0.080 & 0.051 & 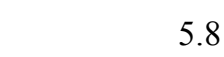 \\
\hline 1988-1997 & -0.007 & -0.021 & -0.051 & 0.051 & 2. \\
\hline
\end{tabular}

Note: This table uses the estimates in Table $3 \mathrm{C}$ and the changes in the respective variables, except for the last column that shows the average level of the agricultural share in the different periods.

\section{Conclusion}

The results suggest that relative prices have a positive but small influence on the share of agriculture in GDP in both the long-run and the short-run. A decline in the relative price of agricultural products is associated with a decline in the share of agriculture in GDP, other things equal. An increase in capital per unit of labor, on the other hand, is associated with a smaller agricultural share. This result is consistent with the Rybczynski Theorem, since agriculture is relatively labor intensive. Technical change has been biased in favor of the agricultural sector but this effect has been swamped by the magnitude of the input effects, in particular, the changes in the capital-labor ratio.

In summary, the strong negative impact of the change in factor endowments seems to have dominated any possible positive effect of relative prices and technical change. This result makes a strong case for a Heckscher-Ohlin type model as a basis of understanding the development of the Taiwanese economy. It also indicates the importance of Taiwan's open economy trade policies as the growth of its capital stock would probably not have been as 
dramatic in the absence of such policies. The export-oriented policy implemented by the Taiwan government led to capital accumulation in industries with comparative advantages in the world market and fostered high economic growth over the last half century. 
Figure 6. Agricultural Share Dynamics: Short and Long Run Effects

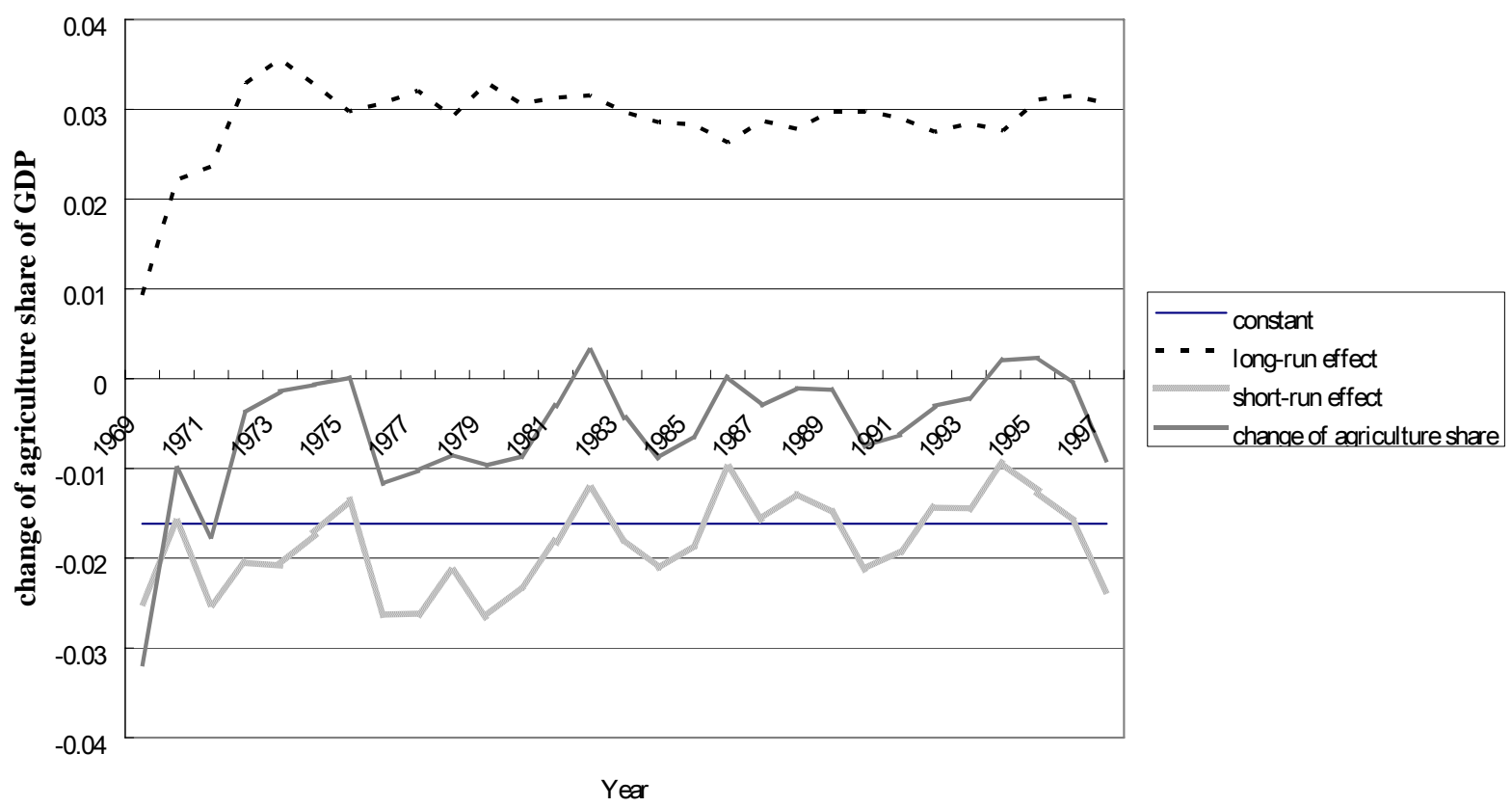

Note: Figure 6 uses the estimates in Table 3 (B-ii), equation (19):

Constant $=-0.016154$;

Short run effect $=0.080252 \Delta \ln (\mathrm{Pa} / \mathrm{Pn}) \mathrm{t}-0.1303 \Delta \ln (\mathrm{K} / \mathrm{L}) \mathrm{t}+0.30117 \Delta \ln (\mathrm{R} / \mathrm{L}) \mathrm{t}$;

Long run effect $=-0.67303 \mathrm{Sa}_{\mathrm{t}-1}+0.058536 \ln (\mathrm{Pa} / \mathrm{Pn})_{\mathrm{t}-1}-0.026293 \ln (\mathrm{K} / \mathrm{L})_{\mathrm{t}-1}+0.15353 \ln (\mathrm{R} / \mathrm{L})_{\mathrm{t}-1}+$ $0.0038639(\mathrm{t}-1)$. 
Figure 7. Agricultural Share Dynamics: Accounting for effect of relative prices, endowments and technical change

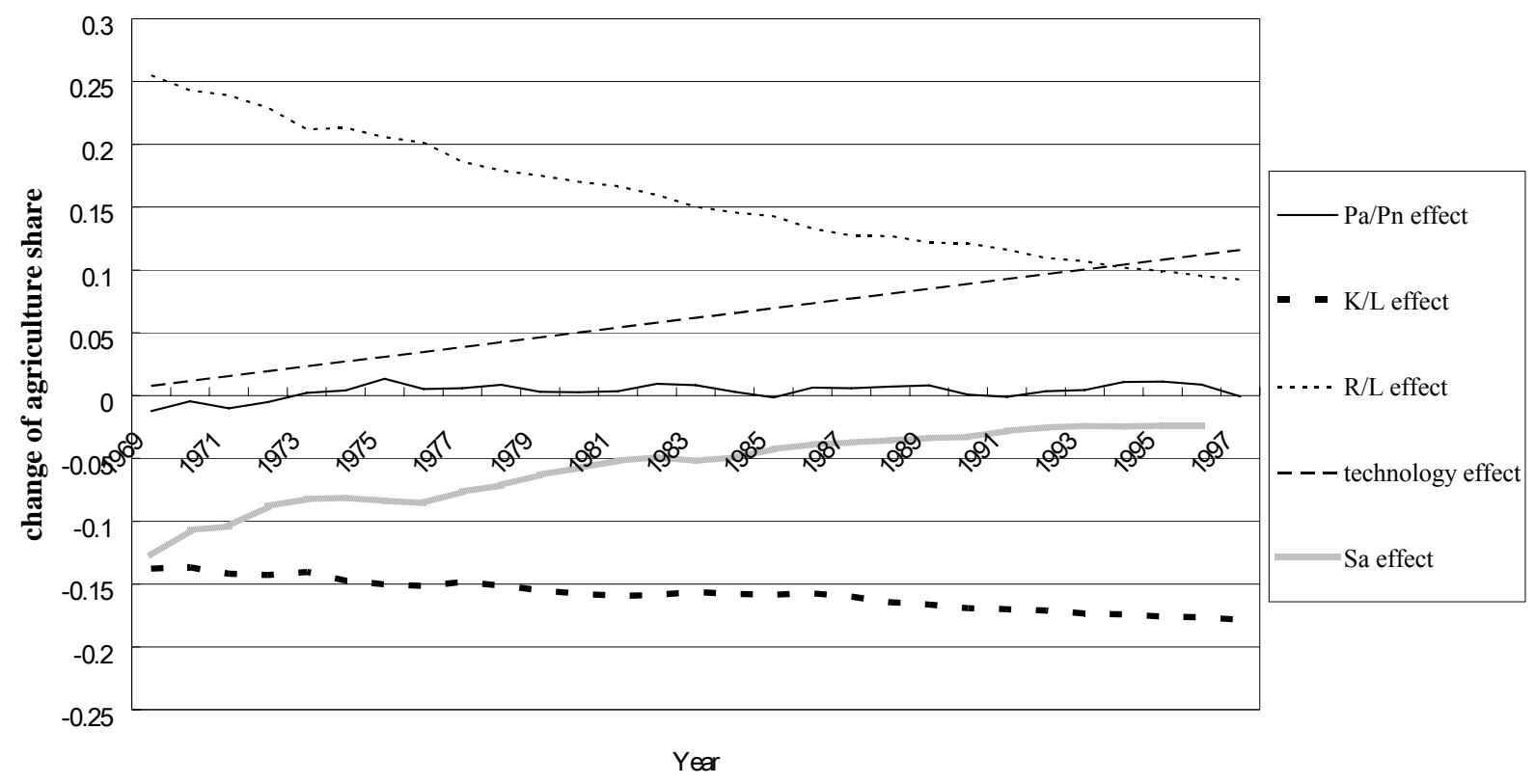

Note: Figure 7 uses the estimates in Table 3-B(ii), equation (19):

$\mathrm{Pa} / \mathrm{Pn}$ effect $=0.080252 \Delta \ln (\mathrm{Pa} / \mathrm{Pn})_{\mathrm{t}}+0.058536 \ln (\mathrm{Pa} / \mathrm{Pn})_{\mathrm{t}-1}$;

$\mathrm{K} / \mathrm{L}$ effect $=-0.1303 \Delta \ln (\mathrm{K} / \mathrm{L})_{\mathrm{t}}-0.026293 \ln (\mathrm{K} / \mathrm{L})_{\mathrm{t}-1}$;

$\mathrm{R} / \mathrm{L}$ effect $=0.30117 \Delta \ln (\mathrm{R} / \mathrm{L})_{\mathrm{t}}+0.15353 \ln (\mathrm{R} / \mathrm{L})_{\mathrm{t}-1}$;

Technology effect $=0.0038639(\mathrm{t}-1)$;

$\mathrm{Sa}$ effect $=-0.67303 \mathrm{Sa}_{\mathrm{t}-1}$. 
Figure 8 Agricultural Share in Steady State: Accounting for effect of relative prices, endowments, and technical change

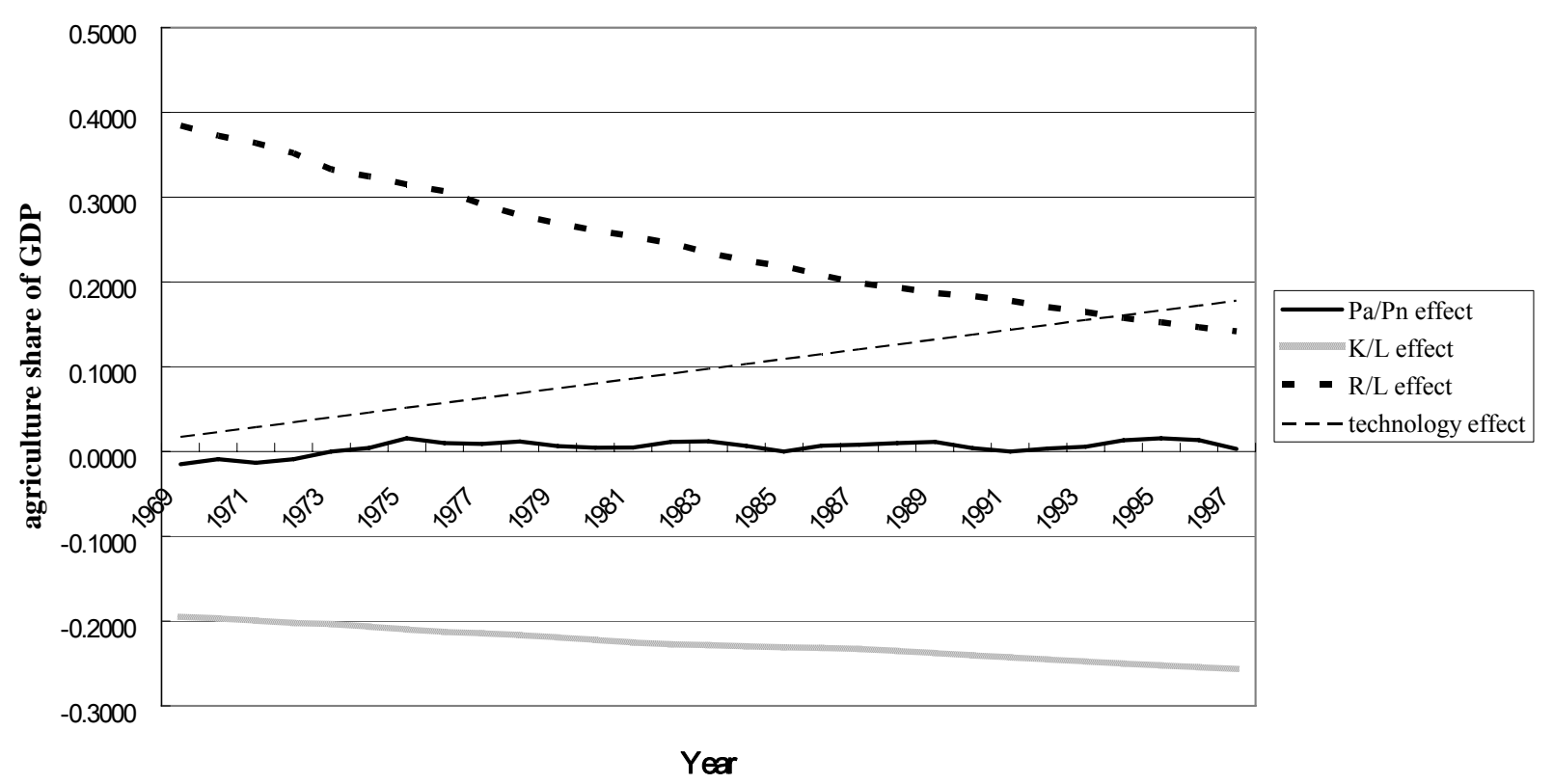

Note: Figure 8 uses the estimates in Table 3-C, equations (20)-(21):

$\mathrm{Pa} / \mathrm{Pn}$ effect $=0.086974 \ln \left(\mathrm{p}_{\mathrm{a}} / \mathrm{p}_{\mathrm{n}}\right)_{\mathrm{t}} ;$

$\mathrm{K} / \mathrm{L}$ effect $=-0.03907 \ln (\mathrm{K} / \mathrm{L})_{\mathrm{t}}$;

$\mathrm{R} / \mathrm{L}$ effect $=0.22812 \ln (\mathrm{R} / \mathrm{L})$;

Technology effect $=0.00574 \mathrm{t}$. 
Table A-1 The Data Set

\begin{tabular}{|c|c|c|c|c|c|}
\hline & $\begin{array}{l}\text { Ag. product } \\
1991 \text { mill NT dollars }\end{array}$ & $\begin{array}{l}\text { Ag. Share } \\
\text { in GDP \% }\end{array}$ & $\begin{array}{c}\text { Ag. Price / } \\
\text { Non Ag. Price }\end{array}$ & Capital/Labor & Land/Labor \\
\hline 1967 & 121442 & 0.2061 & 0.9320 & 132.18 & 5.8174 \\
\hline 1968 & 127433 & 0.1902 & 0.9376 & 137.49 & 5.5377 \\
\hline 1969 & 122370 & 0.1589 & 0.8421 & 146.58 & 5.3922 \\
\hline 1970 & 127598 & 0.1547 & 0.9009 & 152.99 & 5.1161 \\
\hline 1971 & 128672 & 0.1307 & 0.8572 & 164.58 & 4.9236 \\
\hline 1972 & 132534 & 0.1221 & 0.8997 & 175.91 & 4.6734 \\
\hline 1973 & 136657 & 0.1210 & 0.9990 & 181.87 & 4.3026 \\
\hline 1974 & 139656 & 0.1242 & 1.0517 & 197.01 & 4.1487 \\
\hline 1975 & 133944 & 0.1270 & 1.1986 & 214.98 & 3.9781 \\
\hline 1976 & 145007 & 0.1138 & 1.1224 & 232.54 & 3.8382 \\
\hline 1977 & 150509 & 0.1060 & 1.1110 & 241.61 & 3.5870 \\
\hline 1978 & 148941 & 0.0938 & 1.1447 & 254.91 & 3.3913 \\
\hline 1979 & 155851 & 0.0855 & 1.0770 & 273.38 & 3.2536 \\
\hline 1980 & 152729 & 0.0768 & 1.0530 & 295.68 & 3.1358 \\
\hline 1981 & 152149 & 0.0730 & 1.0578 & 318.64 & 3.0458 \\
\hline 1982 & 155881 & 0.0774 & 1.1405 & 336.34 & 2.9338 \\
\hline 1983 & 158659 & 0.0730 & 1.1483 & 345.23 & 2.7908 \\
\hline 1984 & 161507 & 0.0633 & 1.0779 & 356.77 & 2.6831 \\
\hline 1985 & 165090 & 0.0578 & 1.0013 & 367.57 & 2.6060 \\
\hline 1986 & 165020 & 0.0555 & 1.0825 & 373.61 & 2.4869 \\
\hline 1987 & 174687 & 0.0531 & 1.0990 & 386.27 & 2.3858 \\
\hline 1988 & 176514 & 0.0504 & 1.1219 & 410.34 & 2.3345 \\
\hline 1989 & 175550 & 0.0490 & 1.1426 & 436.52 & 2.2711 \\
\hline 1990 & 179200 & 0.0418 & 1.0468 & 468.87 & 2.2350 \\
\hline 1991 & 182356 & 0.0379 & 1.0000 & 499.47 & 2.1818 \\
\hline 1992 & 177115 & 0.0360 & 1.0445 & 529.96 & 2.1095 \\
\hline 1993 & 186747 & 0.0366 & 1.0689 & 566.07 & 2.0561 \\
\hline 1994 & 178581 & 0.0357 & 1.1658 & 599.36 & 1.9960 \\
\hline 1995 & 183189 & 0.0355 & 1.1970 & 636.03 & 1.9502 \\
\hline 1996 & 182060 & 0.0329 & 1.1700 & 669.23 & 1.9030 \\
\hline 1997 & 180984 & 0.0273 & 1.0348 & 708.10 & 1.8629 \\
\hline
\end{tabular}




\section{List of Figures}

Figure 1. GDP in the Agriculture Sector in Taiwan, 1967-1997 (1991 prices)

Figure 2. Agricultural Share in Taiwanese GDP, 1967-1997

Figure 3. Index of Relative Prices of the Agricultural and Nonagricultural Outputs

Figure 4. The Capital-Labor Ratio in Taiwan, 1967-1997

Figure 5. The Land-Labor Ratio in Taiwan, 1967-1997

Figure 6. Agricultural Share Dynamics: Short and Long Run Effects

Figure 7. Agricultural Share Dynamics: Accounting for effect of relative prices, endowments and technical change

Figure 8. Agricultural Share in Steady State: Accounting for effect of relative prices, endowments, and technical change 


\section{REFERENCES}

Anderson, Kym. "On Why Agriculture Declines with Economic Growth,” Agricultural

Economics, 1 (1987):195-207.

Beggs, John.. “On Diagnostic Testing in Applied Economics.” Economic Record, 64(185)

(1988):81-101.

Chambers, Robert G., Rolf Fare and Shawna Grosskopf. "Productivity Growth in APEC

Countries." Pacific Economic Review, 1:3, (1996): 181-190.

Chang, C. C. and Y. H. Luh. "Efficiency Change and Growth in Productivity: the Asian Growth Experience.” Journal of Asian Economics, 10 (2000): 551-570.

Cheng, Shy-Hwa. "Reasons of Taiwan Agriculture Construction Change-Compare with

Japan.” Journal of Agricultural Economics, National Chung-Hsing University Press, Taiwan. (45), June 1989.

Darby, M.R. “The U.S. Productivity Slowdown: A Case of Statistical Myopia.” American Economic Review, 74(3) (1984): 301-322.

Davies Ian. "Taiwan: The Economic Significance of the Industrialization Program.” The American Journal of Chinese Affairs, Vol. 0, Issue 6 (July 1981): 1-20.

Dessus, Sebastien, Jia-Dong Shea and Mau-Shan Shi. "Chinese Taipei: The Origins of the Economic "Miracle." Development Centre of the Organization for Economic Co-Operation and Development, 1995.

Diewert, Erwin and Morrison. "Export Supply and Import Demand Functions: A Production Theory Approach.” In Robert Feenstra, ed., Empirical Methods for International Trade, 
Cambridge, Mass.: MIT Press, 1988.

Dixit, Avinash and Norman. "Theory of International Trade.” Welwyn (England) and Cambridge: J. Nisbet and Cambridge University Press, 1980.

Ericson, Neil. “Co-integration, Exogeneity, and Policy Analysis.” Journal of Policy Modeling, 14(3) (1992): 251-80.

Fare, Rolf, Shawna Grosskopf and W.F. Lee. "Productivity in Taiwanese Manufacturing Industries." Applied Economics, 27 (1995): 259-265.

Fuess, Scott M. Jr. and Hendrik Van Den Berg. "Transactional Activities and Total Factor Productivity Growth in Taiwan.” Journal of Asian Economics, Vol. 7, No. 4 (1996): 635-650. Harberger. "Perspectives on Capital and Technology in Less-Developed Countries." In Artis, M. J. and A. R. Nobay, (eds.), Contemporary Economic Analysis, Croom Helm (1978).

Harrigan, James. "Technology, Factor Supplies, and International Specialization: Estimating the Neoclassical Model.” The American Economic Review, 1997.

Ho, Samuel P.S. "Industrialization in Taiwan: Recent Trends and Problems.” Pacific Affairs, Vol. 48, Issue 1 (Spring 1975): 27-41.

Kikuchi and Hayami. "Agricultural Growth Against a Land Resource Constraint: A Comparative History of Japan, Taiwan, Korea, and Philipines." Journal of Economic History, Vol. 38, Issue 4 (December 1978): 839-864.

Kim, J. I and L J. Lau. "The Sources of Economic Growth of the East Asian Newly Industrialized Countries." Journal of the Japanese and International Economic, Vol. 8 (1994): 235-271. 
Kohli, Ulrich. "Gross National Product Function and the Derived Demand for Imports and Exports." Canadian Journal of Economics, 11(2) (1978): 167-82.

Kohli, Ulrich. Technology, Duality, and Foreign Trade: The GNP Function Approach to Modeling Imports and Exports, Ann Arbor, MI: University of Michigan Press, 1991.

Kongsamut, Piyabha, Sergio Rebelo, and Danyang Xie. "Beyond Balanced Growth," Review of Economic Studies, 68 (2001):869-882.

Lau, Lawrence J. and Pan A. Yotopoulos. “The Meta-Production Function Approach to Technological Change in World Agriculture.” Journal of Development Economics, 31 (1989): 241-269.

Lewis, W. A. "Economic Development with Unlimited Supplies of Labor." Manchester School of Economic and Social Studies, 22 (1953): 239-91.

Liang, Chi-Yuan. “The Total Factor Productivity Growth in Taiwan, 1960-1993: A CounterEvidence to Krugman-Kim-Lau-Young Hypothesis.” Working paper, Asia Conference on Efficiency and Productivity Growth, 2002.

Liang, Chi-Yuan and Dale W. Jorgenson. "Productivity Growth in Taiwan's Manufacturing Industry, 1961-1993.” 1996.

Martin, W. and D. Mitra. "Productivity Growth and Convergence in Agriculture versus Manufacturing," Economic Development and Cultural Change, 49-2 (2001):403-422.

Martin, W. and P.G. Warr. "Determinants of Agriculture's Relative Decline: Thailand.” Agricultural Economics, 11 (1994) 219-235. 
Martin, W. and P.G. Warr. "Explaining the Relative Decline of Agriculture: A Supply-Side Analysis for Indonesia.” World Bank Economic Review, 7 (1993): 381-401.

“Monthly Bulletin of Earnings and Productivity Statistics." Directorate-General of Budget, Accounting and Statistics, Executive Yuan, May 2000, the Republic of China.

Mundlak, Yair. Agriculture and Economic Growth: Theory and Measurement, Harvard University Press, Cambridge, Massachusetts, 2000.

Nerlove, Marc. 1956. "Estimates of Supply of Selected Commodities." Journal of Farm Economic 38:496-509.

Phillips, Peter C. B. and Pierre Perron. "Testing for a Unit Root in Time Series Regression." Biometrika, Vol. 75, No. 2. (June 1988): 335-346.

“Quarterly National Economic Trends Taiwan Area, the Republic of China.” DirectorateGeneral of Budget, Accounting and Statistics, Executive Yuan, Republic of China, August 2000.

Said, E. and David A. Dickey. "Testing for Unit Roots in Autoregressive-Moving Average Models of Unknown Order.” Biometrika, (1984), 71, 3: 599-607.

Sun, Ling. "Industrial Productivity Growth and Openness in Taiwan." Working paper, Asia Conference on Efficiency and Productivity Growth, 2002.

“Taiwan Statistical Data Book.” Council for Economic Planning and Development, Taiwan, Republic of China, 2002.

Weisdorf, Jacob L. "From Domestic Manufacture to Industrial Revolution: Long-Run Growth and Agricultural Development," working paper 04-06, Institute of Economics, University of Copenhagen, Denmark, 2004.

Woodland A.D. "Estimation of a Variable Profit and of Planning Price Functions for Canadian 
Manufacturing, 1947-70.” Canadian Journal of Economics, X, No. 3, August 1977.

Young, Alwyn. "Lessons from the East Asian NICS: A Constrain View." European Economic Review, 38 (1994a):964-73.

Young, Alwyn. "Accumulation Exports and Growth in the High Performing Asian Economics: A Comment." Carregie-Rochester Conference Series on Public Policy, 40 (1994b): 237-50.

Young, Alwyn. "The Tyrrany of Numbers: Confronting the Statistical Realities of the East Asian Growth Experience.” Quarterly Journal of Economics, August 1995: 641-680. 